Original Research Paper

\title{
Utilization of Banana, Pineapple and Watermelon Wastes- Substrate: As Consortiums to Remediating Cyanide Polluted Soil
}

\author{
${ }^{1}$ Florence Obiageli Nduka, ${ }^{2}$ Samuel Chibuike Ubani, ${ }^{2}$ Victor Eshu Okpashi, \\ ${ }^{3}$ Nwankwo NE, ${ }^{2}$ Sandra Ajiroghene Gometi, ${ }^{1}$ Blessing Chika Nwaso and ${ }^{2}$ O.F.C. Nwodo \\ ${ }^{1}$ Department of Applied Sciences, Federal College of Dental Technology and Therapy, Enugu, Nigeria \\ ${ }^{2}$ Department of Biochemistry, University of Nigeria, Nsukka, Enugu, Nigeria \\ ${ }^{3}$ Department of Biochemistry, Renaissance University, Ugbawka, Enugu, Nigeria
}

Article history

Received: 11-02-2018

Revised: $10-04-2018$

Accepted: 28-04-2018

Corresponding Author:

Victor Eshu Okpashi

Department of Biochemistry,

University of Nigeria, Nigeria

Email: vic2reshu@gmail.com
Abstract: The act of processing cassava for varied food products has come with unguided and wide-spread contamination of cyanide in the environment. The need for effective reduction in cost to enable remediation of cyanide-contaminated sites from cassava mill factories is the purpose of this investigation. This involves bio-stimulation of organic wastes with indigenous microorganisms to degrade cyanide. The application of organic wastes as a substrate for the removal of cyanide was adopted. Banana, pineapple, and watermelon wastes were selected and bio-stimulated in cyanide contaminated soil. Each set-up containing $100 \mathrm{~g}$ of Cassava Mill Effluent (CME) contaminated soil was added with varied percent - 1, 5 and $10 \%$ of pineapple, banana, and watermelon waste, respectively. The monitoring of cyanide reduction was studied for 28 days. Periodic collection of soil samples from each set-up was done at four days interval to determine total cyanide concentration, total heterotrophic bacteria, and enzymes activities. Results indicated that after 28 days of applying the $10 \%$ watermelon, $5 \%$ pineapple and $1 \%$ banana waste, the $10 \%$ watermelon waste gave a better cyanide reduction compared to pineapple and watermelon waste treatment. The one phase-decay equation of $1 \%$ banana, $5 \%$ - pineapple and $10 \%$ - watermelon waste treatment gave the shortest disintegration rate. The soil physicochemical properties, agro waste, microbial population, soil enzymes activities, soil microbial respirometric index, the bio-parameters sensitivity, carbon, nitrogen, and phosphorus were determined. The first order kinetics model revealed by the nth order algorithm; pineapple waste treated soil had the highest reduction rate 0.9098 /day of CME with half-life -6.98 days. The $1 \%$ banana and $10 \%$ watermelon treated soil samples have the cyanide reduction rates $0.9315 /$ day and $0.8997 /$ day. The cyanide reduction rate was significantly higher than the untreated contaminated CME (control) soil - 0.8975/day. The microbial counts and the three agrowaste treatment samples increase in day 4-16 $\left(2.20 \times 10^{8}\right.$ to $\left.6.40 \times 10^{8} \mathrm{CFU} / \mathrm{g}\right)$ for $5 \%$ - pineapple; $1 \%$ - banana increased from $20 \times 10^{8}$ to $8.90 \times 10^{8} \mathrm{CFU} / \mathrm{g}$ (day $20-28$ ) and $10 \%$ - banana increased $-1.20 \times 10^{8}$ to $8.70 \times 10^{8} \mathrm{CFU} / \mathrm{g}$ (day $4-20$ ); $1 \%$ - watermelon increased from $8.40 \times 10^{8}$ to $8.80 \times 10^{8} \mathrm{CFU} / \mathrm{g}$ (day 20-24) and $10 \%$ watermelon increased from $-8.10 \times 10^{8}$ to $8.70 \times 10^{8} \mathrm{CFU} / \mathrm{g}$ (day $24-28$ ), than the control which showed increase from $3.40 \times 10^{8}-7.20 \times 10^{8} \mathrm{CFU} / \mathrm{g}$ (day $4-$ 12) during the 28 days of remediation study. Soil organic carbon content 
gave a positive correlation with microbial biomass, carbon, nitrogen, and phosphorus, as well as microbial population, basal soil respiration and soil enzyme - catalase, lipase, dehydrogenase, urease and phosphatase activity. Soil contamination decreased $(\mathrm{p}<0.05)$ catalase, urease and dehydrogenase activities in all the waste treated soil compared to the control set-up. Owing to the use of this agro-waste-banana, pineapple and watermelon has proved to be effective in enhancing soil nutrient, improved soil enzymes activity and removed of cyanide from CME contaminated soil.

Keywords: Cassava Mill Effluent, Agro Waste, Cyanide Remediation and Pollution Control

\section{Introduction}

The effects of cassava effluent on soil contaminated with cyanide are difficult to assess, due to limited data (Igbinosa, 2015). In Nigeria, there is little or no information on eco-toxicological effects of cyanide Cassava Mill Effluent (CME) contaminated soil. In this study, soil samples from cassava mill factories were collected. Studies have shown that contaminants in equilibrium with the polluted soil relate mostly to their occurrence and distribution in the environment. These may provide a good model for determining the long-term effects due to cassava effluents on soil microorganisms. Cassava (Manihot esculenta) belongs to Euphorbiaceae family. It is one of the largest sources of carbohydrate. The output of cassava in the world increased by $4.6 \%$ between 2013 and 2014 (FAO, 2014). Nigeria is the largest producer of cassava with approximately 45 million tons in 2009, which was almost $19 \%$ of production in the world (Adekanye et al., 2013). Cassava can be processed to numerous food products such as akpo, garri, lafun flour, starch, dried wet cassava flour and fermented products (Okechi et al., 2012). Cassava provides a major source of calories to consumers because of its high starch content. Also, the directives for cassava flour in bread baking, boasted the output in cassava production and utilization (Okunade and Adekalu, 2014). The importance of cassava in economic development and food security has provided an increase in processing and waste handling generation (Okunade and Adekalu, 2013). Processing of cassava is associated with a large discharge of effluents accompanied with cyanide (Okechi et al., 2012). Cyanide could pose a serious environmental and public health hazard. Cassava is normally processed before consumption as a means of detoxification, preservation and modification (Obueh and OdesiriEruteyan, 2016). The presence of cyanogenic glycosides with its metabolite in unfermented roots and leaves is implicated in cassava toxicity (Kobawila et al., 2005). Cyanogens and glycosides are easily hydrolyzed into hydrogen cyanide which is toxic to aquatic and terrestrial life with a severe threat to the environment (Abiona et al., 2005). Cyanide is one of the most toxic and lethal chemicals (Seteno and Bruno, 2013). It is among the most deleterious component of organic pollutants with hazard to human health and environment. Currently, cyanide worldwide is estimated at $>14$ million $\mathrm{kg}$ per annum (Gupta et al., 2010). When cyanide interacts with (soil) water, it produces a weak acid (Shape, 1976). Such pollutions could cause a severe imbalance to the biotic and abiotic components of the ecosystem (Igbinosa, 2015). Cassava wastewater influences the acidity of soils when large amounts are added to the soil. Regardless of this hazardous behavior of cyanide in the environment and human health, appropriate treatment of cyanide must be applied in cassava effluent treatment before discharge into the environment. Several processes have been used by industries to remove cyanide. The physical and chemical methods are mostly applied by industries. Even though these different chemical and physical degradation methods are used to reduce the cyanide-related compounds, they require significant capital investment and large quantities of reagents such as chlorine and hydrogen peroxide, which exacerbate environmental pollution. Based on the foregoing, the used of organic waste may be considered as cost-free idea and technology for removing such contaminants/pollutants from the environment. Ubalua (2014) noted that the success of degradation depends on the use of microbes with the physiological and metabolic capabilities to degrade the pollutants in the polluted media.

Most researchers have used soil enzyme to determine the extent of perturbation on soil and it was a successful approach to study the impact of different agricultural inputs on the physicochemical and enzymatic activities of the soil (Graham and Haynes, 2005). Such enzymes include dehydrogenase, urease, polyphenol oxidase, hydrogen peroxidase, acid and alkaline phosphatase (Nwaugo et al., 2008). The need to addressing cyanide polluted soil was carried out on the soil physicochemical properties, catalase, lipase, urease, dehydrogenase and phosphatase, soil microflora and soil respirometric index. The parameters were used as indicators of soil recovered from cassava-cyanide, using agro-waste (organic) as substrate. Different statistical approaches were utilized to identify the most responsive parameters, while the choice of agro-waste was based on their disintegration rate and moisture content. 


\section{Materials and Methods}

\section{Chemicals}

All chemicals used in this study were of analytical grade.

\section{Plant Materials}

The following agro-waste materials - banana waste, pineapple waste and watermelon waste were obtained from Ogige Market in Nsukka, Enugu State. The wastes were air dried and ground to fine-coarse particles and stored in sterile containers. These wastes are in large quantities and usually dumped to decay.

\section{Agro-Wastes Treatment}

Agro-waste samples (banana, pineapple, and watermelon) were prepared by oven-drying the agro-waste at $80^{\circ} \mathrm{C}$ for 7-10 days followed by milling to less than 100 $\mu \mathrm{m}$. The dried agro-waste samples were filtered through a $0.22 \mu \mathrm{m}$ Millipore filter and the debris free extract was used for the experiments at the required concentration.

\section{Collection of Soil Sample}

Disinfected soil auger and hand spade soil samples were collected into sterile glass containers from a depth of $0-20 \mathrm{~cm}$ from soil contaminated with Cassava Mill Effluent (CME) at the Department of Agricultural Science cassava milling plant, University of Nigeria, Nsukka. Soilfree cassava effluent samples were collected from control sites outside the processing site. Samples were collected during the late raining season in October 2016 and stored in labeled plastic until used for analysis. During this period, the raining season has reduced drastically and the run-off of the cassava mill effluent is sufficiently hindered. At this point, the cassava mill effluent begins to permeate the soil, accumulate and partitioned along the soil strata. Therefore, only waste materials with a relatively shorter half-life of disintegration increased microbial mass and high moisture content could be used to feed on the calcified starch and cyanide.

\section{Preparation of Soil Samples}

Soil samples (cassava mill effluent contaminated soil and uncontaminated soil) were air dried for one week in a clean well-ventilated laboratory, homogenized by grinding, sieved with a $2 \mathrm{~mm}$ (10 mesh).

\section{Experimental Design}

The experimental designs were as follows:

Test samples

Normal soil (untreated)

CME contaminated soil

(untreated)

CME contaminated
Method of treatment

(Positive control)

(Negative control)

$(100 \mathrm{~g}$ of soil + banana waste - soil + banana waste

CME contaminated

soil + pineapple waste

CME contaminated

$1,5$ and $10 \%)$

$(100 \mathrm{~g}$ of soil + pineapple

$-1,5$ and $10 \%)$

$(100 \mathrm{~g}$ of soil + watermelon

soil + watermelon waste $-1,5$ and $10 \%$ )

"waste samples were used in different percentages of 1,5 and $10 \%$ " without combination due to their varying rates of disintegration.

\section{Isolation of Microbial Population}

Each soil sample was analyzed for their microflora. The microbial isolation was carried using the standard microbiological technique. One gram of the sample was homogenized in $9 \mathrm{~mL}$ of sterile water and serially diluted in ten-fold dilutions. Aliquots of $0.1 \mathrm{~mL}$ of appropriate dilutions were taken and introduced into Petri dishes containing nutrient agar. The introduced sample was then spread very well in the plates using hockey stick in order to get discrete colonies. The nutrient agar plates were left for some minutes to dry and then incubated at $30 \pm 2^{\circ} \mathrm{C}$ for 24-48 $\mathrm{h}$ for heterotrophic organisms to grow. A distinct colony was thereafter enumerated at the end of incubation. The plates with 30-300 colonies were reported in Colony Forming Unit (CFU) per gram of soil sample. The Colony Forming Units (CFU) per gram of soil samples were calculated using the relationship:

$$
\text { Number of cells }(C F U / g)=a / v \times D
$$

Where:

$a=$ The number of colonies on the plate

$V=$ The volume of diluted cells plated on each agar plate $(0.1 \mathrm{~mL})$

$D=$ The dilution factor $\left(10^{8}\right)$

Soil $\mathrm{pH}$ was determined using 1:2.5 soil - liquid ratio by Black (1965). Mechanical analysis of particle size was carried out by Bouyoucos hydrometer method (1951 modified). Total exchangeable bases, cation exchange capacity (CEc) and Phosphorus was determined by Bray and Kurtz - 2 (1945) method. Organic carbon in soil was determined by Walkley and Black (1934) method. The method for the determination of exchangeable acidity was adopted from Jackson (1970). Percentage concentrations of protein, fat, carbohydrate crude fiber, moisture and ash were determined for banana, pineapple and watermelon peels (agro-wastes) using the AOAC method of (1990). Many of the complex lipids, such as phospholipids are not completely extracted in this procedure (Ensminger and Olentine, 1978). Carbohydrate or Nitrogen Free Extracts (NFE) hemicelluloses and lignin (Cullison, 1982). Soil microbial biomass, carbon, Nitrogen and Phosphorus were determined by the fumigation-extraction method of Vance et al. (1987). Cyanide content of each soil sample 
was determined by a modification of the picric acid method of Fisher and Brown (1952). Soil catalase activity was measured by the method described by $\mathrm{Wu}$ et al. (2016). Soil lipase activity was measured through the colorimetric method (Agnello et al., 2016). Soil urease activity and Soil respiration were determined with a modified method according to Wade et al. (2002).

\section{Statistical Analysis}

Results are expressed in means \pm SD and Standard Error of the Mean (SEM) using the IBM SPSS version 23 software. The principal component analysis was applied to examine the sensitivity of the biological parameters using Minitab 17 software and interpolated with GraphPad Prism version 6.

\section{Discussion}

The mean cyanide level in Cassava Mill Effluent (CME) contaminated soil was higher than the three banana, pineapple and watermelon waste treatment after the experiment. Piva (1987) noted that 75 to $1000 \mathrm{mg}$ cyanide/kg present in cassava roots may differ due to speciation and soil conditions. Oke (1968) reported that the differences in cyanide concentration - 10.4 and 274 $\mathrm{mg} / \mathrm{L}$ depending on the cyanoglycoside content of the cassava species (Kaewkannetra et al., 2009). According to Bengtsson and Triet (1994), the cyanide content of untreated cassava wastewater ranges from 3.2 and 3.5 $\mathrm{mg} \mathrm{CN} / \mathrm{L}$. Boadi et al. (2008), stated that raw cassava and peels contained 114.7 to $159.6 \mathrm{mg} / \mathrm{kg}$ and 360.05 to $509.51 \mathrm{mg} / \mathrm{kg}$ of cyanide, respectively, while Flynn and McGill (1995) assessed the cyanide level in cooked cassava to be -6.79 to $24.91 \mathrm{mg} / \mathrm{kg}$. considering the high level of cyanide in the soil, it is suggested that the cyanide level in the soil differ with species and tendency cyanide to adsorbed or partition in cassava tubers. investigation of the treated soils showed residual cyanide levels, which agreed with the findings of De Lange et al. (1982) cited in Ogundola and Liasu, 2007) on the formation of free cyanide which associated with cyanohydrins hydroxy nitrates and stabilized by glycosylation. According to Ogundola and Liasu (2007), high cyanide concentration may become toxic to soil microorganisms. Considering the high levels of cyanide in the soil samples, one can infer that cyanide may have a direct effect on the large volume of cassava effluent that discharged into environment unguided. The cyanide level in the soil was higher than the permissible levels - $11.00 \mathrm{mg} / \mathrm{kg}$ for soil habitat and agriculture practices and $55.00 \mathrm{mg} / \mathrm{kg}$ for other purposes (National Environment Board, 2004).

The $\mathrm{pH}$ of the cassava effluent was acidic, suggesting that the agro-waste used as substrate did not neutralize the soil pH. This might be due to the conversion of cyanohydrins into ketones and free HCN. The addition of agro-wastes, generated hydrogen ion concentration resulting in the acidic $\mathrm{pH}$, sees Table 1 . The $\mathrm{pH}$ levels could enhance cyanohydrins stability and promote cyanide recalcitrance in the soil. The physicochemical properties of the soil receiving effluent are shown in Table 1. Soil $\mathrm{pH}\left(\mathrm{H}_{2} \mathrm{O} ; \mathrm{KCl}\right)$ value of the contaminated soil indicates that the soil is strongly acidic. The acidity was attributed to hydrogen cyanide in the CME. The $\mathrm{pH}$ values recorded in contaminated soil agreed with the reported of (Iwegbue et al., 2013).

The total nitrogen levels in the cassava mill effluent contaminated soil samples (untreated) and the control soil samples were lower than the cassava mill effluent contaminated soil (treated) with agro-wastes. The total and mineral nitrogen indicate the reserves of organic nitrogen capable of undergoing mineralization under suitable conditions. A total nitrogen level below $0.10 \%$ in soil is considered low for agricultural activities (Odu et al., 1985). The exchangeable bases and Cation Exchange Capacity (CEC) are important properties of soil and sediments. They indicate the ability of a particular soil to sustain plant growth; nutrients retention; buffer acid deposition or isolate toxic heavy metals. Results for the exchangeable bases showed that sodium levels in the untreated soil samples and control samples were lower than the soil samples treated with agro-wastes - banana, pineapple, and watermelon. Potassium levels in the untreated (cassava mill effluent contaminated) soil samples had a higher value than the control soil samples and soil samples treated with agrowastes (Adepoju and Ketiku, 2003). The calcium level in the untreated soil samples was higher than the control and an agro waste treated soil sample. The magnesium levels in the untreated soil samples and control had lower values than the soil samples treated with agro-wastes.

Manganese levels in the control soil samples were low, while the untreated soil samples and agro waste soil treated soil samples had the same effect. Exchangeable bases distribution gives an indication of the relative abundance and availability of some major nutrient elements. A cation content of about $2 \mathrm{meq} / 100 \mathrm{~g}$ soil was considered adequate for $\mathrm{Ca}$ and $\mathrm{Mg}$, while for $\mathrm{K}, 0.2$ $\mathrm{me} / 100 \mathrm{~g}$ soil and above was considered adequate for agriculture (Odu et al., 1985). The soil means for K were generally found to be of required values for certain crops such as plantain, banana etc. The mean exchangeable acidity $\mathrm{H}$ level was higher in the contaminated soil samples than in the control and untreated soil samples. Thus the application of banana, pineapple, and watermelon agro waste slightly increased $\mathrm{pH}$ value of the soil, this increase in soil $\mathrm{pH}$ value was associated with increases in exchangeable acidity which was attributed to the removal of $\mathrm{Al}^{3+}$ from the soil by organic matter decomposition (Adepoju and Onasanya, 2008). Almeida et al. (2012), reported a phase decay for agro-waste treatment soil samples used as a substrate for the removal of cyanide from CME contaminated soil Table 2 .

A number of factors such as low nutrient supplies and low bioavailability of the pollutants generally limits the number of microbial activities in the soil during 
bioremediation process (Ron and Rosenberg, 2014). Thus, it is a well-known fact that cyanide exerts a significant effect on the microbial population in the soil. As observed, there was a relatively significant increase in bacteria cyanide degraders as at day 16 and 20 before experiencing a decline. This may be reduced bioavailability of carbon source and formation of toxic intermediate at the terminal of the bioremediation period. The increases in cyanide degraders of agro-waste treated soil samples and the untreated soil samples were due to microbial population caused by the stimulation of microorganisms (Table 3 ).
The total heterotrophic organism count of cyanidecontaminated soil and the entire soil samples treated with the various agro-wastes were higher compared with the control. In the three agro-waste treatment samples there was increase throughout the 28 days of bioremediation study. This may be due to microbial ecology of the soil or characteristics of the experimental soil. The reason for the higher counts of the bacteria in treated soil may be the result of the presence of appreciable quantities of nitrogen and phosphorus in the agro-wastes (Table 4).

Table 1: Physicochemical parameters of the soils (uncontaminated, contaminated and treated soil) samples during Bioremediation

\begin{tabular}{|c|c|c|c|c|c|}
\hline & Uncontaminated & Contaminated & $\begin{array}{l}\text { Treated with } \\
\text { Banana }\end{array}$ & $\begin{array}{l}\text { Treated with } \\
\text { Pineapple }\end{array}$ & $\begin{array}{l}\text { Treated with } \\
\text { water melon }\end{array}$ \\
\hline Clay \% & $12.60 \pm 0.12^{\mathrm{a}}$ & $13.60 \pm 0.12^{b}$ & $15.60 \pm 0.17^{\mathrm{c}}$ & $15.60 \pm 0.12^{\mathrm{c}}$ & $15.60 \pm 0.12^{\mathrm{c}}$ \\
\hline Silt \% & $5.02 \pm 0.06^{\mathrm{a}}$ & $7.28 \pm 0.01^{\mathrm{b}}$ & $7.20 \pm 0.12^{\mathrm{b}}$ & $9.28 \pm 0.02^{\mathrm{b}}$ & $7.28 \pm 0.02^{\mathrm{c}}$ \\
\hline Fine sand & $32.26 \pm 0.62^{\mathrm{a}}$ & $38.60 \pm 0.12^{\mathrm{e}}$ & $36.04 \pm 0.01^{\mathrm{c}}$ & $37.24 \pm 0.02^{\mathrm{d}}$ & $34.60 \pm 0.12^{\mathrm{b}}$ \\
\hline Coarse sand & $38.76 \pm 0.07^{\mathrm{a}}$ & $40.66 \pm 0.01^{\mathrm{c}}$ & $41.08 \pm 0.01^{\mathrm{d}}$ & $39.78 \pm 0.01^{\mathrm{b}}$ & $42.52 \pm 0.06^{\mathrm{e}}$ \\
\hline pH (Distilled H2O) & $7.70 \pm 0.12^{\mathrm{d}}$ & $5.20 \pm 0.06^{\mathrm{a}}$ & $6.50 \pm 0.06^{\mathrm{c}}$ & $5.70 \pm 0.06^{\mathrm{b}}$ & $7.50 \pm 0.06^{\mathrm{d}}$ \\
\hline pH (KCL) & $7.20 \pm 0.12^{\mathrm{d}}$ & $4.40 \pm 0.06^{\mathrm{a}}$ & $6.50 \pm 0.12^{\mathrm{c}}$ & $5.50 \pm 0.06^{\mathrm{b}}$ & $7.30 \pm 0.06^{\mathrm{d}}$ \\
\hline $\mathrm{CN}^{-}$(mg/100g) & $46.91 \pm 0.02^{\mathrm{a}}$ & $223.50 \pm 0.02^{\mathrm{e}}$ & $69.86 \pm 0.02^{c}$ & $68.62 \pm 0.02^{b}$ & $71.50 \pm 0.02^{\mathrm{d}}$ \\
\hline TOM (\%) & $1.53 \pm 0.01^{\mathrm{a}}$ & $3.05 \pm 0.01^{\mathrm{b}}$ & $8.50 \pm 0.12^{\mathrm{d}}$ & $9.17 \pm 0.01^{\mathrm{e}}$ & $7.96 \pm 0.01^{\mathrm{c}}$ \\
\hline TOC (\%) & $0.89 \pm 0.01^{\mathrm{a}}$ & $1.77 \pm 0.01^{\mathrm{b}}$ & $5.05 \pm 0.01^{\mathrm{d}}$ & $5.32 \pm 0.01^{\mathrm{e}}$ & $4.64 \pm 0.01^{\mathrm{c}}$ \\
\hline TN(\%) & $0.05 \pm 0.00^{\mathrm{a}}$ & $0.25 \pm 0.00^{\mathrm{b}}$ & $0.94 \pm 0.02^{\mathrm{e}}$ & $0.29 \pm 0.00^{\mathrm{c}}$ & $0.36 \pm 0.00^{\mathrm{d}}$ \\
\hline $\mathrm{Na}^{+}(\mathrm{me} / 100 \mathrm{~g})$ & $0.03 \pm 0.00^{\mathrm{a}}$ & $0.63 \pm 0.01^{\mathrm{b}}$ & $1.03 \pm 0.00^{\mathrm{c}}$ & $1.11 \pm 0.00^{\mathrm{d}}$ & $1.14 \pm 0.01^{\mathrm{e}}$ \\
\hline $\mathrm{K}^{+}(\mathrm{me} / \mathbf{1 0 0 g})$ & $0.15 \pm 0.00^{\mathrm{a}}$ & $11.74 \pm 0.01^{\mathrm{c}}$ & $0.52 \pm 0.01^{\mathrm{b}}$ & $0.52 \pm 0.01^{\mathrm{b}}$ & $0.52 \pm 0.01^{\mathrm{b}}$ \\
\hline $\mathrm{Ca}^{2+}(\mathrm{me} / 100 \mathrm{~g})$ & $1.80 \pm 0.01^{\mathrm{a}}$ & $83.30 \pm 0.06^{\mathrm{d}}$ & $66.00 \pm 1.15^{\mathrm{c}}$ & $64.70 \pm 0.12^{\mathrm{c}}$ & $52.00 \pm 1.15^{\mathrm{b}}$ \\
\hline $\mathrm{Mg}^{2+}(\mathrm{me} / \mathbf{1 0 0 g})$ & $0.38 \pm 0.01^{\mathrm{a}}$ & $6.31 \pm 0.01^{\mathrm{b}}$ & $9.46 \pm 0.01^{\mathrm{d}}$ & $9.33 \pm 0.02^{\mathrm{c}}$ & $10.32 \pm 0.01^{\mathrm{e}}$ \\
\hline $\mathrm{Mn}^{2+}(\mathrm{me} / 100 \mathrm{~g})$ & $0.02 \pm 0.00^{\mathrm{a}}$ & $0.05 \pm 0.00^{\mathrm{b}}$ & $0.05 \pm 0.00^{\mathrm{b}}$ & $0.07 \pm 0.00^{\mathrm{c}}$ & $0.05 \pm 0.00^{\mathrm{b}}$ \\
\hline CEC (mel/100g) & $9.18 \pm 0.01^{\mathrm{a}}$ & $70.40 \pm 0.06^{\mathrm{d}}$ & $66.80 \pm 0.23^{c}$ & $64.80 \pm 0.06^{\mathrm{b}}$ & $74.80 \pm 0.06^{\mathrm{e}}$ \\
\hline$P(p p m)$ & $23.08 \pm 0.59^{\mathrm{a}}$ & $362.68 \pm 0.01^{\mathrm{b}}$ & $607.48 \pm 0.00^{\mathrm{d}}$ & $555.08 \pm 0.01^{\mathrm{c}}$ & $612.02 \pm 0.00^{\mathrm{e}}$ \\
\hline H (me/100g) & $0.60 \pm 0.12^{\mathrm{a}}$ & $5.00 \pm 0.58^{\mathrm{e}}$ & $1.60 \pm 0.12^{b}$ & $2.80 \pm 0.06^{\mathrm{c}}$ & $1.40 \pm 0.06^{\mathrm{ab}}$ \\
\hline $\mathrm{Al}^{3+}(\mathrm{me} / \mathbf{1 0 0 g})$ & Nil & Nil & Nil & Nil & Nil \\
\hline
\end{tabular}

Results were expressed in Mean \pm SD. Number of sample $(n=5)$

Table 2: Parameter of one phase decay equation for agro-waste treatment of samples estimated

\begin{tabular}{|c|c|c|c|c|c|c|c|c|}
\hline Treated samples & & Y0 & Plateau & $\mathrm{K}$ & Span & Half-life & Tau & $\mathrm{R} 2$ \\
\hline \multirow[t]{2}{*}{ Contaminated soil } & Estimate & 0.4368 & 0.0385 & 01077.0000 & 0.3983 & 6.438 & 9.288 & 0.8975 \\
\hline & Std. Error & 0.0550 & 0.0030 & 0.0130 & 0.0540 & & & \\
\hline \multirow{2}{*}{ Contaminated soil $+1 \%$ Banana waste } & Estimate & 0.4277 & 0.0089 & 0.1284 & 0.4187 & 5.398 & 7.788 & 0.9315 \\
\hline & Std. Error & 0.0600 & 0.0020 & 0.0130 & 0.0590 & & & \\
\hline \multirow[t]{2}{*}{ Contaminated soil $+5 \%$ Banana waste } & Estimate & 0.4377 & -0.0070 & 0.0985 & 0.4447 & 7.037 & 10.150 & 0.9202 \\
\hline & Std. Error & 0.0190 & 0.0010 & 0.0050 & 0.0180 & & & \\
\hline \multirow[t]{2}{*}{ Contaminated soil $+10 \%$ Banana waste } & Estimate & 0.4393 & 0.0230 & 0.1035 & 0.4163 & 6.699 & 9.665 & 0.8947 \\
\hline & Std. Error & 0.0640 & 0.0030 & 0.0140 & 0.0630 & & & \\
\hline \multirow[t]{2}{*}{ Contaminated soil $+1 \%$ Pineapple waste } & Estimate & 0.4460 & 0.0047 & 0.0849 & 0.4412 & 8.163 & 11.780 & 0.8910 \\
\hline & Std. Error & 0.1160 & 0.0120 & 0.0310 & 0.1100 & & & \\
\hline \multirow[t]{2}{*}{ Contaminated soil $+5 \%$ Pineapple waste } & Estimate & 0.4397 & -0.0014 & 0.0993 & 0.4411 & 6.977 & 10.070 & 0.9098 \\
\hline & Std. Error & 0.0220 & 0.0010 & 0.0050 & 0.0210 & & & \\
\hline \multirow[t]{2}{*}{ Contaminated soil $+10 \%$ Pineapple waste } & Estimate & 0.4434 & 0.0067 & 0.0918 & 0.4367 & 7.549 & 10.890 & 0.8997 \\
\hline & Std. Error & 0.0950 & 0.0090 & 0.0250 & 0.0910 & & & \\
\hline \multirow[t]{2}{*}{ Contaminated soil $+1 \%$ Watermelon waste } & Estimate & 0.4456 & 0.0108 & 0.0767 & 0.4348 & 9.038 & 13.040 & 0.8664 \\
\hline & Std. Error & 0.2030 & 0.0320 & 0.0630 & 0.1860 & & & \\
\hline \multirow[t]{2}{*}{ Contaminated soil $+5 \%$ Watermelon waste } & Estimate & 0.4430 & 0.0054 & 0.0836 & 0.4376 & 8.292 & 11.960 & 0.8910 \\
\hline & Std. Error & 0.1690 & 0.0230 & 0.0510 & 0.1570 & & & \\
\hline \multirow[t]{2}{*}{ Contaminated soil $+10 \%$ Watermelon waste } & Estimate & 0.4335 & 0.0098 & 0.1077 & 0.4240 & 6.437 & 9.287 & 0.9239 \\
\hline & Std. Error & 0.0820 & 0.0050 & 0.0210 & 0.0790 & & & 0.9989 \\
\hline
\end{tabular}


Table 3: Effect of CME on microbial population of soil (CFU/g) bio-stimulated with agro-wastes

\begin{tabular}{|c|c|c|c|c|c|c|c|}
\hline No. of Days & 4 & 8 & 12 & 16 & 20 & 24 & 28 \\
\hline $\begin{array}{l}\text { Contaminated } \\
\text { Banana }\end{array}$ & $3.40 \times 10^{8}$ & $2.80 \times 10^{8}$ & $7.20 \times 10^{8}$ & $1.10 \times 10^{8}$ & $3.40 \times 10^{8}$ & $3.00 \times 10^{8}$ & $2.90 \times 10^{8}$ \\
\hline $1 \%$ & $8.90 \times 10^{8}$ & $2.30 \times 10^{8}$ & $3.40 \times 10^{8}$ & $1.60 \times 10^{8}$ & $1.00 \times 10^{8}$ & $8.20 \times 10^{8}$ & $8.10 \times 10^{8}$ \\
\hline $5 \%$ & $2.70 \times 10^{8}$ & $3.20 \times 10^{8}$ & $4.20 \times 10^{8}$ & $3.90 \times 10^{8}$ & $4.00 \times 10^{8}$ & $2.50 \times 10^{8}$ & $2.80 \times 10^{8}$ \\
\hline $10 \%$ & $5.60 \times 10^{8}$ & $1.20 \times 10^{8}$ & $6.20 \times 10^{8}$ & $4.70 \times 10^{8}$ & $2.30 \times 10^{8}$ & $8.70 \times 10^{8}$ & $6.10 \times 10^{8}$ \\
\hline $\begin{array}{l}\text { Pineapple } \\
1 \%\end{array}$ & & $1.60 \times 10^{8}$ & $2.00 \times 10^{8}$ & $3.90 \times 10^{8}$ & $2.60 \times 10^{8}$ & $1.80 \times 10^{8}$ & $2.00 \times 10^{8}$ \\
\hline $5 \%$ & $\begin{array}{l}1.80 \times 10^{8} \\
3.70 \times 10^{8}\end{array}$ & $1.70 \times 10^{8}$ & $2.20 \times 10^{8}$ & $3.40 \times 10^{8}$ & $5.90 \times 10^{8}$ & $6.40 \times 10^{8}$ & $4.00 \times 10^{8}$ \\
\hline $10 \%$ & $3.50 \times 10^{8}$ & $8.20 \times 10^{8}$ & $3.50 \times 10^{8}$ & $5.40 \times 10^{8}$ & $4.40 \times 10^{8}$ & $4.10 \times 10^{8}$ & $3.80 \times 10^{8}$ \\
\hline $\begin{array}{l}\text { Watermelon } \\
1 \%\end{array}$ & $8.80 \times 10^{8}$ & $3.60 \times 10^{8}$ & $8.40 \times 10^{8}$ & $2.30 \times 10^{8}$ & $2.70 \times 10^{8}$ & $8.40 \times 10^{8}$ & $8.40 \times 10^{8}$ \\
\hline $5 \%$ & $3.60 \times 10^{8}$ & $1.70 \times 10^{8}$ & $4.20 \times 10^{8}$ & $2.40 \times 10^{8}$ & $3.00 \times 10^{8}$ & $5.50 \times 10^{8}$ & $4.00 \times 10^{8}$ \\
\hline $10 \%$ & $8.70 \times 10^{8}$ & $1.10 \times 10^{8}$ & $3.30 \times 10^{8}$ & $2.70 \times 10^{8}$ & $3.30 \times 10^{8}$ & $3.00 \times 10^{8}$ & $8.10 \times 10^{8}$ \\
\hline
\end{tabular}

The number of samples $(\mathrm{n}=5)$. Agrowaste $=$ banana, pineapple and watermelon

Table 4: Soil enzyme activities of CME contaminated soil treated with agro-wastes and control soil

\begin{tabular}{|c|c|c|c|c|}
\hline & Control & $\begin{array}{l}\text { Treated with } \\
\text { Banana }\end{array}$ & $\begin{array}{l}\text { Treated with } \\
\text { Pineapple }\end{array}$ & $\begin{array}{l}\text { Treated with } \\
\text { watermelon }\end{array}$ \\
\hline Catalase $\left(\mu \mathrm{mol} \mathrm{g}{ }^{-1} h^{-1}\right)$ & $46.69 \pm 0.06^{\mathrm{d}}$ & $37.14 \pm 1.06^{\mathrm{c}}$ & $31.40 \pm 1.15^{\mathrm{a}}$ & $34.10 \pm 1.19^{b}$ \\
\hline Dehydrogenase $\left(\mathrm{mg} \mathrm{g}^{-1} \mathrm{~h}^{-1}\right)$ & $61.37 \pm 0.13^{\mathrm{a}}$ & $84.23 \pm 0.05^{\mathrm{d}}$ & $72.18 \pm 0.06^{\mathrm{c}}$ & $64.08 \pm 0.06^{\mathrm{b}}$ \\
\hline Lipase $\left(\mathrm{mg} \mathrm{g}^{-1} \mathrm{~h}^{-1}\right)$ & $14.50 \pm 0.06^{\mathrm{d}}$ & $13.40 \pm 0.06^{\mathrm{c}}$ & $12.40 \pm 0.01^{\mathrm{b}}$ & $12.10 \pm 0.01^{\mathrm{a}}$ \\
\hline Phosphatase $\left(\mathrm{mg} \mathrm{kg}^{-1} \mathrm{~h}^{-1}\right)$ & $5.91 \pm 0.05^{\mathrm{a}}$ & $12.12 \pm 0.58^{\mathrm{c}}$ & $11.12 \pm 0.58^{\mathrm{b}}$ & $13.12 \pm 0.58^{\mathrm{d}}$ \\
\hline Urease $\left(\mu \mathrm{g} \mathrm{g}^{-1} \mathrm{~h}^{-1}\right)$ & $149 \pm 1.06^{\mathrm{d}}$ & $126.82 \pm 0.00^{\mathrm{c}}$ & $103.10 \pm 0.00^{\mathrm{a}}$ & $124.58 \pm 0.00^{b}$ \\
\hline
\end{tabular}

Results were expressed as Mean \pm SD. No. of the sample $(n=5)$. Agro-waste $=$ banana, pineapple and watermelon

Soil enzyme activities have been reported to be adequate indicators for monitoring soil pollution because they act as catalysts, including the decomposition of organic amendments and the degradation of toxic complex substances (Zhang et al., 2014).

As reported by Zhang et al. (2014), the change in microbial biomass carbon is a reflection of the process of organic matter degradation, microbial growth, and death. The untreated soil samples showed a significant decrease in microbial biomass carbon, followed by a relatively stationary phase of microbial biomass carbon within day 20 and 24 , then accompanied by a relative increment in day 28. This trend could be as a result of the low availability of degradable nutrients since cyanide is a complex source of carbon for microorganisms but later became accessible with time. However, it was observed that in the three different agro-wastes (banana, pineapple, and watermelon) treated soil samples, there was an initial decrease in microbial biomass carbon which could have occurred as a result of inaccessibility of nutrients for the microbial growth, though it might be an assumption. This trend remained relatively stable in days 4-16 until a significant difference in microbial biomass - carbon was observed in week 20, with a sharp increase.

The use of soil microbial enzymes activities as bioindicators for bioremediation, the principal component analysis was used in to evaluate the degree of sensitivity of the five different enzymes analyzed in the cassava mill effluent contaminated soil treated with three different agro-wastes samples. Three enzymes were identified where $95 \%$ total variance was elucidated, that is, $95 \%$ responses of soil enzymatic activities were accounted for by three the enzymes. The first, second and third components explained the variation of the cumulative variance. The loading plot obtained from the performed principal component showed - urease, catalase, and dehydrogenase activities were the principal enzymes which were most sensitive to the bioremediation of the treated cassava mill effluent contaminated soil samples (Table 5). Thus, these three enzymes are sufficient to account for soil enzymatic activities in response to the degradation. Urease activity was the most responsive and supports previous reports on the use of urease as a good indicator of soil alteration. 
Table 5: Soil enzymes and soil microbial activities

\begin{tabular}{llll}
\hline & First component & Second & Third \\
\hline & & Component & Component \\
Soil enzymatic activity & Urease & Catalase & Dehydrogenase \\
(95\% total variance) & $50.2 \%$ & $28.6 \%$ & $16.9 \%$ \\
Soil microbial enzymatic activity & Microbial & Microbial & Microbial \\
(97\% total cumulative variance) & biomass carbon & biomass nitrogen & biomass phosphorus \\
& $35.9 \%$ & $34.5 \%$ & Cfu/g \\
\hline
\end{tabular}

However, this report also agrees to the finding of (Igbinosa, 2016) which suggests urease, dehydrogenase and catalase activity as a good relationship between enzymatic inhibition and effluent contamination.

The identification of total heterotrophic bacteria (CFU/g) count as a strong monitoring tool in agro waste samples used as a substrate in bioremediation was not surprising as literature has reported that the cellulosic content of agro-wastes as an amendment could account for the high growth of the microbial population.

\section{Conclusion}

This study used banana, pineapple, and watermelon waste to treat soil polluted with cassava mill effluent, presumably with cyanide as a major toxicant. The treatment proved effective by degrading about $98 \%$ total cyanide in soil samples contaminated with cassava mill effluent. The analysis of the different biological parameters showed that the initial high level of cyanide in the soil decreased considerably during the bioremediation process. However, the enumeration of microbial population, microbial biomass carbon, nitrogen, and phosphorus proved to be the most responsive biological monitoring tools amongst other biological parameters evaluated.

\section{Acknowledgment}

We sincerely appreciated our supervisor Doctor C. S. Ubani for his time and knowledge for monitoring this investigation together with the laboratory technician.

\section{Author's Contributions}

Florence Obiageli Nduka: Participated in the field, laboratory work and gathering of literature.

Samuel Chibuike Ubani: Supervised, designed and edited the draft.

Victor Eshu Okpashi: Wrote the manuscript and interpreted the data.

Nwankwo NE: Did the literature review.

Sandra Ajiroghene Gometi: Did the laboratory work. Blessing Chika Nwaso: Did the field work.

O.F.C. Nwodo: CO-Supervised the research work.

\section{Conflict of Interest}

The author(s) hereby declare no competing interest regarding the publication of this manuscript.

\section{References}

Abiona, O.O., L. Sanni and O. Bambgose, 2005. An evaluation of microbial load, heavy metals and cyanide contents of water sources, effluents and peels from three cassava processing locations. J. Food Agric. Environ., 3: 207-208.

Adekanye, T.A., S.I. Ogunjimi and A.O. Ajala, 2013. An assessment of cassava processing plants in Irepodun Local Government Areas, Kwara State, Nigeria. World J. Agric. Res., 1: 14-17.

Adepoju, O.T. and A.O. Ketiku, 2003. Chemical composition and contribution of shea butter (Butyrospermum paradoxum) fruit pulp to nutrient intake of its consumers. J. Tropical Forestry Resid, 19: 20-28.

Adepoju, O.T., and L.O. Onasanya, 2008. Nutrient composition and antinutritional factors of Dialium guineense Wild fruit pulp. Ife J. Sci., 10: 33-37.

Agnello, A.C., D. Huguenot, E.D. Van Hullebusch and G. Esposito, 2016. Citric acid and tween 80 assisted phytoremediation of a co-contaminated soil. Environ. Sci. Pollut. Res., 23: 9215-9226. DOI: $10.1007 / \mathrm{s} 11356-015-5972-7$

Almeida, O.P., J. Pirkis, N. Kerse, M. Sim and L. Flicker et al., 2012. A Randomized Trial to Reduce the prevalence of depression and self-harm Behaviour in Older Primary Care Patients. Am. J. Geriatric Psychiatry, 20: 433-440.

AOAC, 1990. Official Methods of Analysis. In: Association of Official Analytical Chemists, AOAC (Ed.), Washington, D.C., pp: 220-224.

Bengtsson, B. and T. Triet, 1994. Tapioca-starch wastewater toxicity characterized by microtox and duckweed tests. Ambio, 23: 473-477.

Black, C.A., 1965. Methods of soil analysis Part 2. Agronomy Series, 9: 149-178.

Boadi, N.O., S.K. Twumasi and J.H. Ephraim, 2008. Impact of cyanide utilization in mining on the environment. Int. J. Environ. Res., 3: 101-108.

Bouyoucos, G.J., 1951. Improved hydrometer method for making particle size analysis. Agronomy J., 54: 464-465.

DOI: 10.2134/agronj1962.00021962005400050028x 
Bray, R.H. and L.T. Kurtz, 1945. Determination of total organic and available forms of phosphorus in soils. Soil Sci., 59: 30-45. DOI: $10.1097 / 00010694-194501000-00006$

Cullison, A.E., 1982. Feeds and Feeding. 3rd Edn., Reston Publishing Company Incorporated Virginia, USA.

De Lange, S., M. Boscoe and T.H. Stanley, 1982. Catecholamines and Cortisol responses to high dose sufentanil and alfentanil- $\mathrm{O}_{2}$ anesthesia during coronary artery surgery. Anesthesia, 61: 177-178.

Ensminger, M.E. and C.G. Olentine, 1978. Feed and Nutrition-Complete. 1st Edn., The Ensminger Publishing Company, California, pp: 1057.

FAO, 2014. Food and agricultural organization of the United Nations FAOSTAT Database. FAO, Rome, Italy.

Fisher, F.B. and J.S. Brown, 1952. Colorimetric determination of cyanide in stack gas and water. Analytical Chem., 24: 1440-1444. DOI: $10.1021 / \mathrm{ac} 60069 \mathrm{a} 014$

Flynn, C.M. and S.L. McGill, 1995. Cyanide chemistryprecious metals processing and waste treatment. U.S. Bureau Mines, NTIS Public., 96: 117-841.

Graham, M.N. and R.J. Haynes, 2005. Organic matter accumulation and fertilizer induced acidification interact to affect management experiment. Biol. Fertility Soil, 41: 249-256.

DOI: 10.1007/s00374-005-0830-2

Gupta, N., C. Balomajumder and V.K. Agarwal, 2010. Enzymatic mechanism and biochemistry of cyanide degradation: A review. J. Hazard Mater., 176: 1-13. DOI: $10.1016 /$ j.jhazmat.2009.11.038

Igbinosa, E.O., 2015. Effect of cassava mill effluent on the biological activity of soil microbial community. Environ. Monitor. Assessment, 187: 418-418. DOI: $10.1007 / \mathrm{s} 10661-015-4651-y$

Igbinosa, E.O., 2016. Detection and antimicrobial resistance of Vibrio isolate in an aquaculture environment. Implic. Public Health Microbiol. Drug Resistance, 22: 238-245.

Iwegbue, A.O.J., I.O. Oghenerhoro and I.J.C. Egbai, 2013. Investigation of environmental noise pollution level of Abraka in Delta State, Nigeria. Trends Applied Sci. Res., 3: 292-297.

Jackson, M.L., 1970. Soil Chemical Analysis. 1st Edn., Prentice Hall of India, New Delhi, pp: 115.

Kaewkannetra, P., T. Imai and F.J. Garcia, 2009. Cyanide removal from cassava mill wastewater using Azotobactor vinelandii TISTR 1094 with mixed microorganisms in the activated sludge treatment system. J. Hazard Mater., 172: 224-228. DOI: 10.1016/j.jhazmat.2009.06.162
Kobawila, S.C., D. Louembe, S. Keleke, J. Hounhouigan and C. Gambe, 2005. Reduction of the cyanide content during fermentation of cassava roots and leaves to produce bike and ntobambodi, two food products from Congo. Afr. J. Biotechnol., 4: 689-696.

National Environment Board, 2004. Soil quality standards. Notification of National Environmental Board No. 25 BE Royal govt. gazette No. 121 special part 119D.

Nwaugo, V.O., R.A. Onyeagba, E.I. Akubugwo and O. Ugbogu, 2008. Soil bacterial flora and enzymatic activities in zinc and lead-contaminated soil. Biochemistry, 20: 77-84.

Obueh, H.O. and Odesiri-Eruteyan, 2016. A study on the effects of cassava processing wastes on the soil environment of a local cassava mill. J. Pollut. Effects Control, 4: 177-181. DOI: $10.4176 / 2375-4397.1000177$

Odu, C.T.I., O.F. Esuruoso, I.C. Nwoboshi and J.A. Ogunwalu, 1985. Environmental Agip oil company operation area. A report submitted to Nigeria Agip Oil Company, Ltd., Lagos, Nigeria.

Ogundola, A.F. and M.O. Liasu, 2007. Herbicidal effects of effluent from processed cassava on growth performances of Chromolaena odorota weeds population. Afr. J. Biotechnol., 6: 685-690.

Oke, O.L., 1968. Cassava as food in Nigeria. World Ver Nutritional Dietet., 96: 227-250.

Okechi, R.N., C.E. Ihejirika, N.A. Chiegboka and I.J. Ibe, 2012. Evaluation of the effects of cassava mill effluent on the microbial populations and physicochemical parameters at different soil depths. Int. J. Biosci., 2: 139-145.

Okunade, D.A. and Adekalu, 2013. Physico-chemical analysis of contaminated and water resources due to cassava wastewater effluent disposal. Eur. Int. J. Sci. Technol., 2: 75-84.

Okunade, D.A. and Adekalu, 2014. Characterization of cassava-waste effluents contaminated soils in Ile-Ife Nigeria. Int. J0. Sci. Technol., 3: 173-182.

Piva, G., 1987. An evaluation of feeding stuff: Alternatives for poultry diets. Feed Int.

Ron, E.Z. and E. Rosenberg, 2014. Enhanced bioremediation of oil spills in the sea. Curr. Opin. Biotechnol., 27: 191-194. DOI: $10.1016 /$ j.copbio.2014.02.004

Seteno, K.O.N. and A.Q.S. Bruno, 2013. Potential of AgroWaste Extracts as Supplements for Continuous Bioremediation of Free Cyanide Contaminated Wastewater. 1st Edn., World Academy of Science, Engineering and Technology, pp: 76.

Shape, A.G., 1976. Percentages of Cyanocomplexes of the Transition Metals. 1st Edn., Academic Press, London. 
Ubalua, A.O., 2014. Production and Optimization of extracellular $\alpha$-amylase production from Bacillus subtilis. Afr. J. Microbiol. Res., 8: 3761-69.

Vance, E.D., P.C. Brookes and D.S. Jenkinson, 1987. An extraction method for measuring soil microbial biomass C. Soil Biology and Biochemistry, Pergamon J. Ltd, 19: 703-707.

Wade, J.W., E. Omoregie and I. Ezenwata, 2002. Toxicity of cassava (Manihot esculenta Crantz) effluent on the Nile Tilapia, Oreochromis niloticus $(L)$ under laboratory condition. J. Aquat. Sci.., 17: 89-94. DOI: $10.4314 /$ jas.v17i2.19918
Walkley and I.A. Blank, 1934. Methods of soil analysis soil science.

Wu, L.O., B. Hasekamp, B. Van-Diedenhoven, J.E.Y. Cairns and J. Chowdhary, 2016. Passive remote sensing of aerosol layer height using near-UV multiangle polarization measurements. Geophys. Res., 43: 8783-8790; DOI:10.1002/2016GL069848

Zhang, Q.Z., F.A. Dijkstra, X.R. Liu, Y.D. Wang and J. Huang et al., 2014. Effects of biochar on soil microbial biomass after four years of consecutive application in the North China Plain. PLoS ONE, 9: 1-8. DOI: 10.1371/journal.pone.0102062 